\title{
Geography and Power: Mapping The Murderer's Ape
}

\section{Tatjana Kielland Samoilow ${ }^{1}$ (D)}

Accepted: 3 February 2022

(c) The Author(s) 2022

\begin{abstract}
Geography occupies a central role in The Murderer's Ape (2014/2017), a Swedish children's novel by Jakob Wegelius. Drawing on theories of critical literary geography, the article is an analysis of the novel's geography and an exploration of how the narrative shapes and produces place and space. The analysis shows that the narrative both represents and challenges colonial power structures through the production of place and space. Methodologically, three complementary approaches are utilized: analyzing the visual maps in the endpapers, visualizing the novel's geography by means of GIS-generated maps, and mapping the verbal narrative.
\end{abstract}

Keywords Children's literature · Literary geography · Postcolonialism · Power · Subversion · Mapping

My eyes searched here and there and eventually found Bhapur. It was a small princedom almost at the top of the map and at the foot of the Himalayas, in the part of India called the Punjab. I worked out that it must be about eight hundred miles from Karachi to Bhapur, and if the train kept a speed of thirty-five miles an hour we would be there within twenty-four hours. (Jakob Wegelius, 2014/2017, p. 278)

The searching eyes belong to Sally Jones, the gorilla narrator of the Swedish novel The Murderer's Ape by Wegelius (2014/2017). On her way to India to solve a crime, she is betrayed, tricked and sold to a British industrialist who plans to give

\footnotetext{
Tatjana Kielland Samoilow is an Associate Professor in Norwegian literature and didactics. She works with literature at the intersection between aesthetics and politics. She is the author of the book Kritisk teori i litteraturundervisningen (Critical Theory in Literary Education, 2020), the editor of Barn og katastrofer. Sosiokulturelle perspektiver på barns skriveprosesser (Children and Catastrophies. Socio-Cultural Perspectives on Children's Writing, 2020) and the author of several articles on picture books. She is a member of the editorial board of Nordic Journal of ChildLit Aesthetics.
}

Tatjana Kielland Samoilow

tatjana.samoilow@ntnu.no

1 Department of Teacher Education, Norwegian University of Science and Technology (NTNU), Trondheim, Norway 
her to an Indian prince, the maharaja of Bhapur. By reading, measuring and comprehending a map of British India, she verbally maps a part of India, allowing the reader to reconstruct her travel route and connect the narrative to the visual map enclosed in the novel's endpapers. In the narrative's colonial setting in the 1920 s or 1930s, maps have symbolic value. As Anderson (2014, p. 164) points out, geographical maps have "profoundly shaped the way in which the colonial state imagined its dominion." Maps are also a fundamental part of early adventure fiction, a literary form associated with the ideologies of British colonialism (cf. Bradford, 2007; Bushell, 2015; Posti, 2017). When Sally Jones reads the map, however, it is not to territorialize and conquer. In Wegelius' universe, Sally Jones is a citizen of the world, and neither colonizer nor colonized. She uses the map to gain freedom and subvert power. It is this relationship between geography and power that will explored in this article.

The novel blends detective and adventure novel elements with those of a political thriller while also incorporating fantastic features. The rich illustrations and short chapters, the adventure plot and the gorilla narrator appeal to young readers; meanwhile, the political plot, the adult environment and social issues, the historical references as well as the advanced vocabulary and the novel's complex structure and different diegetical levels appeal to more mature readers. The Murderer's Ape opens on the ship Hudson Queen in the harbor of Lisbon. Here, Sally Jones sits at a typewriter and documents her adventures over the last 4 years. She recounts how she and her human companion Henry Koskela were entangled in a political plot that led to Koskela's conviction for the murder of Alphonse Morro, whose body was never found. She recounts how she was hunted as a murderer's ape in Lisbon's Alfama district, but made friends with the fado singer Ana Molina. And she recounts how she discovered that Morro was still alive, and traveled to India to find him; how she was tricked by a man she had considered her friend, and given to the maharaja of Bhapur; how she became the maharaja's friend and was eventually reunited with Ana, returned to Lisbon, found Morro and freed Koskela.

The Murderer's Ape's themes of power and geography have both been the topic of critical discussion. In their analysis of professional and young readers' responses to digital texts, Palo and Manderstedt (2019) focus on the main character Sally Jones, specifically her intersectionality. They argue that while the gorilla narrator belongs to several marginalized groups-animals, women, working class-she nevertheless transgresses such categories, and thus "Sally Jones proffers a vantage point for evaluating the categories and boundaries that define the other characters" (Palo and Manderstedt, 2019, p. 132). Posti also examines the gorilla's intersectionality, arguing that Wegelius is creatively reformulating an alterity discourse (2017, p. 194). She analyzes the novel's prequel The Legend of Sally Jones with reference to The Murderer's Ape and reads Wegelius' universe as a critique of colonialism and a rewriting of the adventure novel genre (2017, p. 195). Another approach is taken by Lyngstad and Samoilow (2022, forthcoming) who argue that the novel can be read as an expression of a cosmopolitical ideal in the tradition of Goethe. Geography is identified as an important aspect of the novel in two reception studies (Johnsrud 2020; Palo \& Manderstedt 2018). Remarkably, Palo and Manderstedt (2018) found that none of the readers in their study commented on the illustrations of the maps 
in the endpapers. However, there exists as yet no in-depth analysis. This article will contribute to the discussions on power, colonialism and subversion that especially Posti and Palo and Manderstedt have begun. However, instead of focusing on the narrator, the novel's geography is under scrutiny. This will also allow for a contribution to the field of literary geography in children's fiction, and to introduce visual mapping as a tool for literary analysis - a so-far largely neglected field in children's literature research (cf. Pavlik and Bird, 2017).

The main argument is that geography and power are closely linked in the novel, and that the narrative constructs the utopia of a free world without borders and hierarchies. One of the novel's main subversive strategies is to produce two competing senses of space: colonial and global. By drawing on theories related to what literary geographer Andrew Thacker (2017) terms a critical literary geography, I argue that the novel presents and ultimately challenges colonialism through its construction of place and space. Thacker suggests we should ask "complex questions about space and power, and how space and geography affect literary forms and styles" (Thacker, 2017, p. 33). The literary critic should draw on various critical concepts and examine multiple geographical aspects in a narrative-including how places are represented, how spatial aspects are influenced by social space (such as layout and narrative form) and how maps function in the narrative. In this way the critic should "analyze the spatial histories revealed in text and [...] use this geographical knowledge to understand further the meanings of texts" (Thacker, 2017, p. 36) while not reducing the text to a cultural artefact. Inspired by Thacker's approach, the production of space (Lefebvre, 1974/1991) will be explored through a multi-methodological approach: the starting point is a visual analysis of the maps in the endpapers, detailing how they create colonial space while challenging it at the same time. To get a more exact idea of the novel's geography, how the narrative produces different senses of place and space and how geography and power are interconnected, the novel will be mapped by plotting the text's toponyms (place names) on a map with the help of the geographical information system ArcGis. Thirdly, the verbal narrative is mapped as well.

\section{Geography and Power}

The idea of the production of space is developed by the French Marxist thinker Henry Lefebvre in The Production of Space (La production de l'espace) (1974/1991). A key notion is that our spatial reality is not a given, but rather a social construct, and so historically and culturally marked. Therefore, the "object of interest must be expected to shift from things in space to the actual production of space" (Lefebvre, 1974/1991, p. 37). Space is produced by three different, but interdependent and dialogical elements: (1) social practices in actual locations (perceived space), (2) representations of space (conceived space), and (3) representational spaces (lived space) which Lefebvre describes as "space as directly lived through its associated images and symbols" (Lefebvre, 1974/1991, p. 39). In the case of our novel, colonial space is produced by a combination of actual, perceivable spaces (e.g. Lisbon and India), by representations of space (the maps in the endpapers), 
and by the way places are symbolically marked and defined as colonial space (e.g. through the naming of places that marks them as British). Of course, Lefebvre's triad cannot be directly transferred to the realm of fiction. In fiction, there is no real space, only its referent; the fictional work is already a representation, complicating the idea of perceived, conceived and lived spaces. However, it is enlightening to study the way perception, conception and living are represented in the narrative. Furthermore, conceived space is doubled in fiction: it is both represented through the narrative, and conceived in the reader's imagination. The reader's involvement is especially important in the context of children's literature; as Peter Hunt (2015, p. 23) says, space is a "negotiation [...] between the adult writer and the child reader". Lefebvres' theory complicates the conceptual distinction between the idea of an empty and abstract space and a more specific place, two key concepts in literary geographies (cf. Thacker, 2017). ${ }^{1}$ For the purposes of this article, place is defined as concrete, meaningful and plottable, while space is used in a wider ideological sense: colonial and global.

\section{Mapping the Novel-Methodological Considerations}

The methodology for the visualized mapping of the novel is influenced by Italian literary critic Franco Moretti. In Atlas of the European Novel, Moretti (1998) develops a method for mapping authorships and genres by plotting toponyms on a map. The maps he creates do not merely show where a narrative is set. Rather, they are "analytical tools that pose new questions, and force you to look for new answers" (Moretti, 1998, p. 4). Moretti explains his method in straightforward terms: "you select a textual feature, find the data, put them on paper-and then you look at the map. In the hope that the visual construct will be more than the sum of its parts: that it will show a shape, a pattern that may add something to the information that went into making it" (1998, p. 13). Thus, mapping does not merely involve plotting places on a map, but requires close interaction with and analysis of the text.

I began mapping The Murderer's Ape by marking every toponym in the text. Inspired by the classification of places developed by Piatti et al. (2009) in the project A Literary Atlas of Europe, I differentiated between places of action, projected places (that characters remember or dream of) and markers (places that are merely mentioned). ${ }^{2}$ On the basis of the gathered data, I compiled a number of lists comprising the place names, their frequency and the associated geographic coordinates (longitude and latitude). The lists corresponded to the following questions: Where does the action take place? What does the novel's complete geography look like

\footnotetext{
${ }_{1}$ Lefebvre himself did not go into detail on the distinction between space and place, and it has become a highly contentious topic in critical discussion. For example, Andrew Merrifield (1993) conceptualizes the two concepts in the article "Place and Space: a Lefebvrian Reconciliation".

${ }^{2}$ I also carried out a frequency analysis using the original Swedish text. For the purpose of the argument in the article, I found the simple maps sufficient.
} 
when every place name mentioned in the text is included? What is the geography of India and Lisbon? What does the characters' geography look like?

The list was then connected to the ArcGis map-generating database, using a base map from 1939 with borders that should - for the most part-match the borders of the novel's setting. With the exception of the maps over India and Lisbon, I marked cities and countries, but not streets.

Several issues arose during the process. For one thing, many of the places Sally Jones visits on her travels are merely mentioned, and function as markers. I have nevertheless chosen to map them as part of the narrative. Also, places are frequently both places of action and projected places, e.g. when the narrator recalls an earlier point in the narrative. I have mapped such places as places of action. The mapping of large areas_-such as oceans, rivers, deserts or whole continents-was also an issue, as such places cannot be mapped accurately. I have therefore omitted them from the map; in this way, the novel's actual geography goes beyond what can be visualized. Finally, there is the matter of fictional places. Almost all places in The Murderer's Ape refer to actual locations, but there are two places I could not locate: the maharaja's palace and Agiere. Both are central to the narrative. The novel informs us that the palace is in Bhapur in India, and that Agiere lies along the river Zezere, not far from Constancia, Santarem. I have thus mapped these toponyms to represent the novel's two fictional places.

The kind of mapping I have conducted has drawn some criticism for overrating the objectivity of the method (cf. Thacker, 2017). However, the maps are not used out of quasi-positivist ambition; their purpose is to show the connection between geography and power, one of the narrative's central themes, and to provide additional insights for the analysis of the novel as well as how the novel's geography corresponds to the historical geography. I stress the importance of combining mapping with text reading throughout and the self generated maps should be considered as complementary to the other analysis.

\section{The Geography of The Murderer's Ape}

The first and last thing that meets the reader's eye upon opening and closing the book are the maps in the endpapers (Fig. 1).

Together, these maps display parts of Europe, Africa and Asia, mainly India. They blend abstract, topographical, and pictorial elements to show varying landscapes as well as a symbolic representation of the places from an oblique anglean angle often seen in children's literature (Goga, 2015). A number of places are indexed, travel routes are traced with dotted lines in different colors, and some places are marked with a red dot. The maps thus fulfill the three basic functions that Sundmark (2019) assigns to maps in children's literature-namely "to produce an imaginative space for the reader [...] reference the main events of the storyline, as well as index the places in which these occur" (p. 123). The place indexing makes it easier for young readers to follow the main character's travel route. As is typical of maps for children, pictorial representation is granted precedence over topographical accuracy (Sundmark, 2019)—some regions are marked 

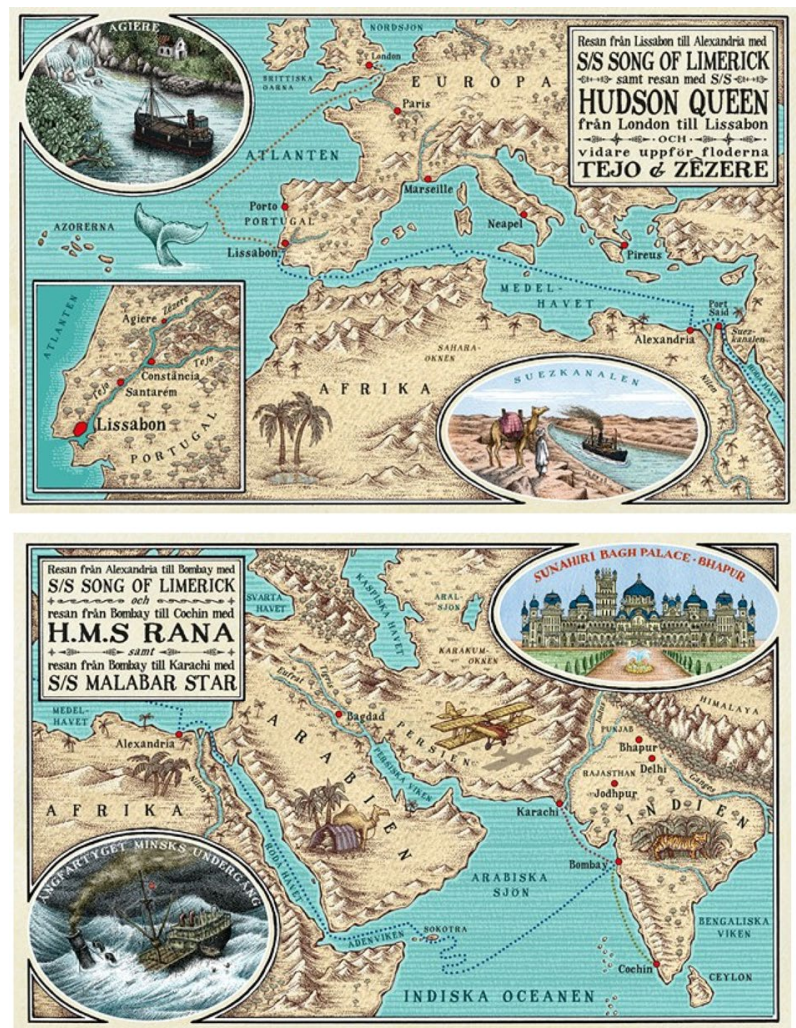

Fig. 1 The maps shown are in the front and back endpapers of the Swedish novel

with relatively high detail, while others are very generally labeled, e.g. "Europe" or "Africa". There is no scale reference and no compass rose. The maps' scale is disproportional; the whale tail, for instance, is as large as Portugal. Meanwhile, Portugal's borders are unclear, but it seems disproportionally large compared to Spain. Another typical feature for maps in children's books is that the novel's maps are supplemented by images that partly foreshadow the plot and portray the most important means of transport (Goga, 2015)_boat and plane, in this case. The text in the corner boxes explains how the maps should be read and once again establishes the travel route.

A major point in literary geography, as well as in the field of critical cartography, is that maps never represent reality as it is. Building on deconstructionist theory, particularly Jacques Derrida, J. B. Harley urges us to "read between the lines of the map - 'in the margins of the text' — and through its tropes to discover the silences and contradictions that challenge the apparent honesty of the image. We begin to learn that cartographic facts are only facts within a specific cultural perspective" (Harley, 2002/1989, p. 153). A map is always ideological, and it is therefore essential to examine what is visualized in what way, and what is hidden. 


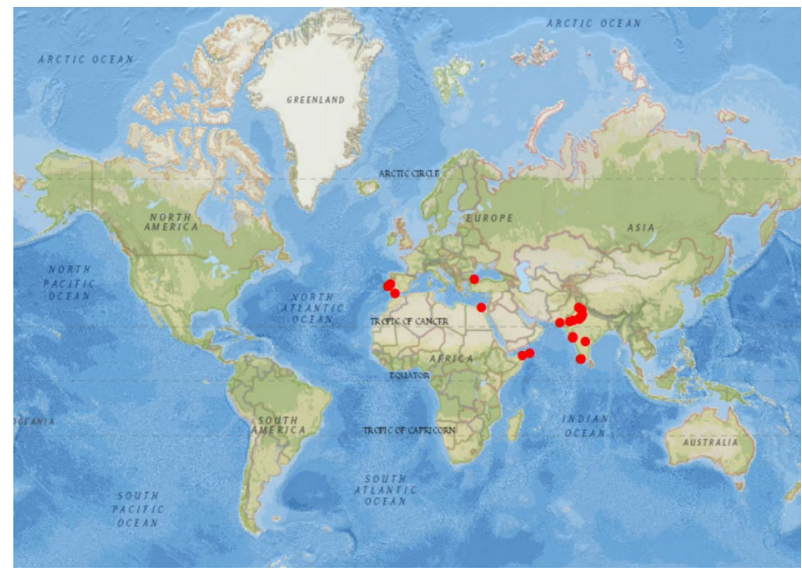

Fig. 2 Map of action

When we look at the maps in Wegelius' novel, what we see visualized is colonial space. The maps display a famous route between the Mediterranean and India via the Suez Canal, which opened in 1869 and "figures prominently in the story of colonialism" (Page and Sonnenburg, 2003, p. 662). Several of the marked places on the travel route are central to colonial history. As Goga (2015, p. 134) points out, maps not only represent space, but express ideas and experiences of time. In The Murderer's Ape the maps' artistic arrangement lends them historical flair and brings to mind other products for children - particularly board games, which themselves contribute to an Orientalist discourse (Robinson, 2014) and to a "nostalgia for empire" that, as Said (1993, p. 12) stresses, "we must take stock of". This reference is enhanced by the images, which exoticize the Middle East and India through depictions of a tiger, camels and a person living in a tent. While the maps can thus be said to participate in colonial discourse, they also engage in another discourse: that of a free, global world. The maps do not show borders and thus do not present the biopolitical power structures of the narrative's time, instead creating a world that is free to travel.

This challenging discourse grows more pronounced when we compare the written narrative's geography with the maps in the endpapers. The maps in the endpapers focus on the travel part of the narrative, and the geography they depict mostly overlaps with the geography of the "map of action" (Fig. 2) I have created myself:

As this map shows, the narrative references far more place names than the endpaper maps, and the narrative's level of geographic specification is higher. Furthermore, as we can see when we compare the authorial maps in the book with this reader map, not all of the places marked on the maps in the endpapers are actually part of the action; London, Paris and Marseille are not actual plot settings, but merely markers and projected places. London is given a particularly prominent place in the endpapers, both marked and referred to in the text box. In the narrative itself, London is merely mentioned several times as part of the backstory. 


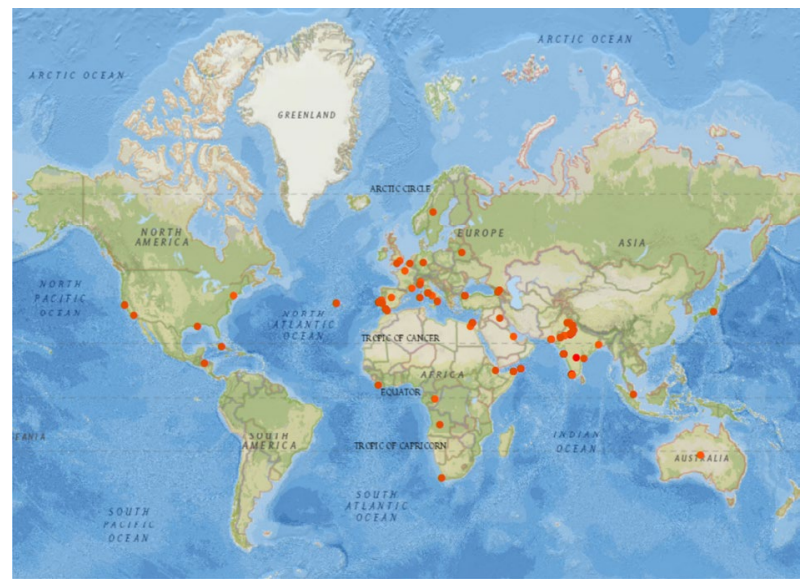

Fig. 3 The novel's complete geography

It is where Sally Jones and Koskela take on cargo bound for the Azores, a place they never reach because a storm forces them to anchor in Lisbon. The inclusion of London on the map has two effects: it anchors the geography for the reader by providing a well-known place, and it visualizes that although Lisbon is the narrative's geographical starting point, it is not Sally's point of departure, making the novel's classical home-away-home structure ambivalent (Lyngstad \& Samoilow, 2022, forthcoming).

From a cultural point of view, the subordinate role Great Britain plays as a geographical place in the novel is striking. As Moretti points out, the literary geographer can reveal two things: "what could be in the novel-and what actually is there" (Moretti, 1998, p. 13). In light of Great Britain's historical position and its relationship with India, one could expect it to be a central place, even a power center. Instead, Wegelius makes Lisbon and thus Portugal the novel's geographical centera nation that lost its economic and colonial power in 1822, with the independence of Brazil (Page and Sonnenburg, 2003, p. 484).

While the plot centers on Lisbon, India and the travel route between these places, the novel's complete geographical scope is much grander. In total, I have plotted 107 toponyms (including street names), covering every continent on the globe (Fig. 3).

Piatti et al. point out that "the distribution of topographic markers will provide an idea of the geography of an author, a genre of literature, or a certain time period" (2009, p. 186). What the map reveals, then, is that the world of the 1920s and 1930s is imagined as globally connected. At the same time, some places are far more dominant than others. The novel's geography thus produces both a global and a colonial sense of space. 


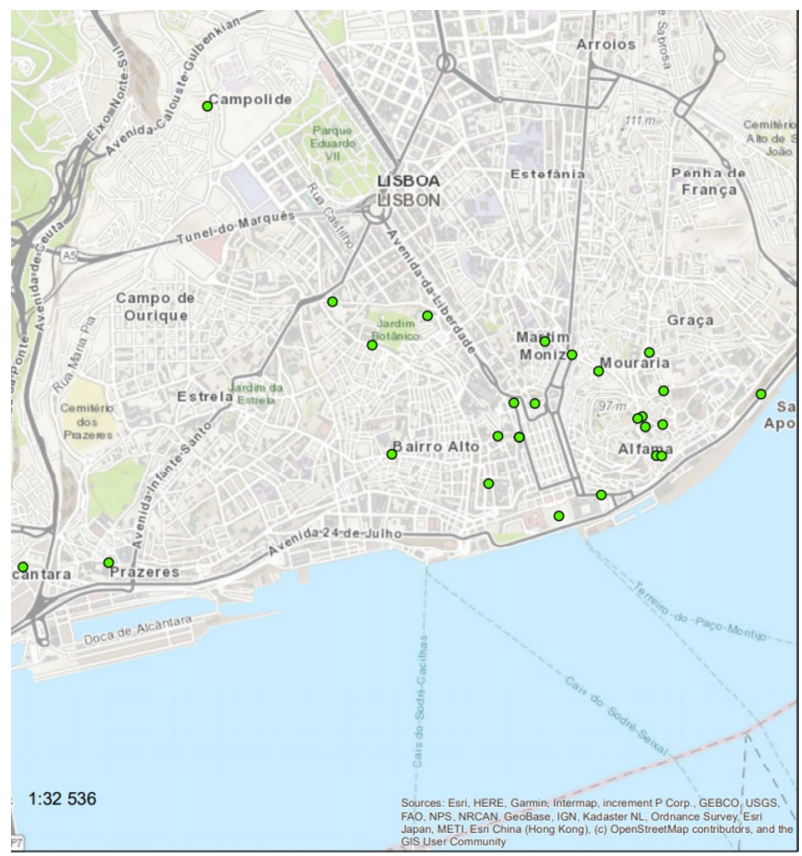

Fig. 4 Map of Lisbon, extract

\section{Shaping a Global Sense of Space: Lisbon}

While the endpapers highlight the novel's spaciousness, the narrative itself begins in a specific place: on the ship Hudson Queen in Lisbon's Alfama district harbor. Most of the novel's plot in parts one and three is set in this city. The sole exception is Sally Jones' and Koskelas' trip to Algiere, where they take on cargo that turns out to be weapons intended to aid a royalist plot to overthrow Portugal's republican government and reinstall King Manuel; this episode leads to the Hudson Queen being damaged and run aground and eventually to Koskelas' arrest for murder. Other than this, the narrator concentrates on Lisbon, which is described in lush and vivid detail to create a strong sense of place.

A close-up of the map of Lisbon (Fig. 4) reveals that the narrative describes the city with a high level of topographical detail. And indeed, the narrative invokes a sense of walking through the city streets, particularly those of the Alfama district. This level of specification is unusual for realistic children's fiction. Swedish children cannot be expected to have detailed knowledge about Lisbon, or to be familiar with the language reflected in these place names. As a consequence, while the topographic specification makes the novel hyperrealistic, it also emphasizes the distance between the reader and the narrative's geography. As Jon Hegglund (2012, p. 10) points out in his geographical exploration of modernist postcolonial novels, an "overload of geographical detail [has] the effect, ironically, of denaturalizing the 'background' spaces of fiction". At the same time, however, the frequent repetition 
of place names - the Rua de São Tomé, for example, is mentioned 26 times-goes some way towards renaturalizing these places. In combination with multiple descriptions, the novel's place names give the impression of Lisbon as a lively and compact city; the notion of close proximity is underscored by the characters moving through the city either by foot or by tram.

In the novel, Lisbon is shown to be a city divided. On the one hand, it is a place of high culture and grandeur, boasting numerous churches, opera and theater houses and other landmarks that hark back to Lisbon's former maritime and colonial power. On the other, the city's colonial and cultural greatness finds a contrast in the poor Alfama district, where the largest part of the novel's action takes place. In the beginning of the novel, the district is described as follows:

Our mooring in the harbor was below the Alfama district, a poor quarter of the city, sleepy by day and full of danger by night. No one batted an eye at the Siamese twins who sold shoelaces on Rua de São Pedro, nor the Devil Dancers from the Pepper Coast who were to be found in the darkest alleyways when the moon was waning. In Alfama they didn't even bat an eye at an ape in a boiler suit, and that was good for me. (Wegelius, 2014/2017, p. 7)

Poor, seedy and full of suspicious individuals, Alfama is the perfect place for plotting crimes, political conspiracies and deceit. As Moretti (1998, p. 35) underscores: "Each genre possesses its own space, then-and each space its own genre", stressing the importance of literary space and place. Alfama's dark and scary harbor is necessary for Wegelius' crime plot, which leads to Alphonse Morro's disappearance and Koskela's arrest. However, though Alfama is depicted as dangerous at night, the real danger lies in the richer parts of the city. This is where the bishop - the leader of the royalist terrorists-resides. Meanwhile, the Alfama district becomes Sally Jones' home and allows her to make friends. It is a place for the powerless, the underdogs - and thus a place for subversion. The novel presents Lisbon both as a form of critical spatial practice - a city environment critiqued and reshaped by means of the characters' movement through it-and as representational space that encodes values and cultural practices. The sense of the city grows out of the combination of these presentations of space.

As argued earlier, the novel creates both a colonial and a global sense of space. This also applies to the depiction of Lisbon. The city holds a number of colonial remnants, including the above-mentioned buildings, and on two occasions, the text refers to Portuguese colonies: when Ana Molina-the poor fabric worker and fado singer who rescues Sally Jones and becomes her friend-is writing to her sister, a missionary in Africa, and when the doctor who diagnoses Alphonse Morro with malaria refers to his time in Angola, one of Portugal's largest colonies at the time. There is only a single explicit reference to Portugal as an empire, however; when Alphonse Morro in a letter reveals how he got entangled with the terrorists and where he was after Koskela's arrest, he writes that he took a boat to "the Portuguese colony of Goa". It is remarkable that there are no other direct references to Portuguese colonialism, particularly considering that it was the Portuguese explorer Vasco da Gama's discovery of the sea route to India that made European imperialism possible (Page and Sonnenburg, 2003, p. 159). The novel's travel route (Figs. 1 
and 2) retraces da Gama's route from 1497, adapted for late imperialism: from Lisbon along the African coast to India, but through the Suez Canal. However, these traces of colonialism - which can hardly be expected by a child reader with little knowledge of colonial history-depict Portugal as a former colonial power at most. The trivialisation of Portugal's role in European imperialism is underlined in Kochi in India, where Sally Jones learns that the Portugese founded the city, "But now the only time you hear Portuguese spoken is among the seamen in the harbor" (Wegelius, 2014/2017, p. 408). The novel deliberately depicts Portugal as an underdog rather than a major imperialistic force, even though the country still held an extensive colonial empire in the 1920s and 1930s, and upheld colonial policies throughout the reign of totalitarian prime minister António de Oliveira Salazar (1932-1968) (Page and Sonnenburg, 2003, p. 516).

Rather than the impression of being a seat of colonial power, the novel's Lisbon gives the reader what Massey (1991) calls a global sense of place. Its harbor holds ships from around the globe, turning the city into an international hub. It is a place to meet people from all over the world: Koskela is Finnish, Ana's neighbour Signor Fidardo is Italian, Sally Jones meets the American-Italian musician Fabulous Forzini at Signor Fidardo's place, and Sally Jones hires her passage to India on the Irish ship Song of Limmerick. Lisbon's diversity is so immense that people don't even take note of a gorilla. At the same time, the names of places and people-Rua de São Pedro, Jorge, Eliza Gomez, Raoul Garetta and so on-as well as the focus on fado singing also give the reader a culture-specific impression. Overall, the narrative presents Lisbon as a positive, multicultural place. There are violent political power disputes between the republicans, the royalists and the anarchists who killed Morro's fiancé, but Lisbon-and by extention Portugal—is not depicted as an abuser of power.

\section{Shaping Colonial Space and Challenging It: India}

Like Lisbon, India is portrayed as an international and global hub. However, while colonial traces are marginal in the depiction of Lisbon, in India the reader meets British India. Upon arrival in Bombay, the Song of Limmerick anchors at the Queen Victoria Dock, and later departs from the King Albert Dock. When Sally Jones is taken hostage and put on the train, she reads the sign Great Indian Peninsula Railway (written in English in the Swedish original text). Underneath the railroad sign is a map of British India. Throughout the Indian narrative, place names mark India as British territory. The colonial presence is depicted critically, and the novel simultaneously evokes colonial discourse and subversion.

The Indian map of action (Fig. 5) shows that the novel creates a different sense of space in India than it does in Lisbon.

In contrast to the compressed city space of Lisbon, India is presented as a vast subcontinent. While the number of place names is similar, the Indian toponyms designate regions, excepting only the streets and districts of Kochi. The sense of size is further enhanced by the changing landscapes Sally Jones travels through-from crowded cities to jungle to desert-like strips of land. In Lisbon, the characters move 


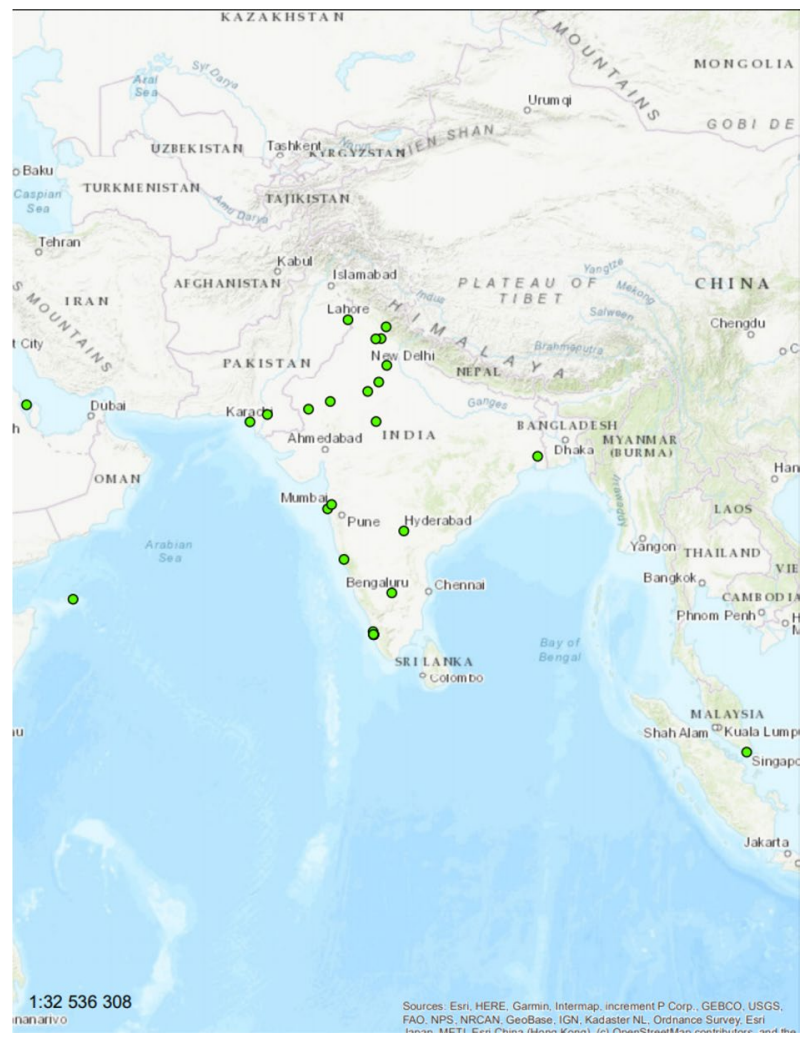

Fig. 5 Map of India

around the city quickly by foot and tram, but in India, movement is slow and never conducted by foot. Here, Sally Jones travels by train, plane, boat or-in Kochi-by rickshaw.

Both the impression of vastness and that of India's state as a colony are underlined by Sally Jones' train travel and repeated readings of maps, as both maps and the railway function as symbolic markers of colonialism. The Indian railway, financed by the British, was one of the greatest communication revolutions during the colonial period (Page and Sonnenburg, 2003, p. 135); it played a vital part in the British exploitation of the subcontinent. As has been mentioned, maps are an important instrument of colonial power. They "were not merely neutral representations of imperial territory; by submitting these territories to the common language of latitude and longitude, they forced the heterogenity and chaos of far-flung colonial places into a seamless graticule of abstract, instrumentalized space" (Hegglund, 2012, p. 88). Like the naming of places, maps turn placesin all their individuality and heterogenity-into territorial property that can be owned by a foreign power. 
Sally Jones employs maps to plot her travel route and calculate distances. While the visual maps in the novel do not disclose distances, the narrative does; the protagonist's approximate travel time-which later proves to be a week rather than the initially assumed $24 \mathrm{~h}$-also allows readers to imagine the large distances involved. However, she uses maps not to gain dominion, but rather to navigate freely in the world. On several instances, she studies maps to calculate water depth and ensure safe sailing. When she is a prisoner in the maharaja's palace, she reads maps to help her plan her escape. In this context, it is telling that when she is taken prisoner upon leaving Lisbon, "someone is leaning on the map table" (Wegelius, 2014/2017, p. 201), thus obscuring the geography and symbolically taking away Sally's freedom of movement. In the novel's narrative structure, the map is not a sign of imperialism, but undermines it by granting personal freedom.

\section{The Rulers and the Ruled: The Indian Maharaja and His Territory}

All of the main characters' individual freedom is linked to geography and mobility in some way. The narrator Sally Jones is a globetrotter who seeks freedom through geographical knowledge. Henry Koskela loses his freedom by being locked in prison, immobile. Ana Molina's movement is initially restricted to her home in the Rua de São Tomé and her work place, a shoe factory in Alcanterra. After Sally Jones scares off Ana's abusive boyfriend Jorge in chapter 19, Ana liberates herself from her constraints, dramatically expanding her geography first within Lisbon and eventually in the world, as does her fado. In "A Global Sense of Place", geographer Massey (1991) analyses what she calls the power geometry of social groups and their position in and relations to the globalized world: "Different social groups have distinct relationships to this anyway differentiated mobility: some people are more in charge of it than others; some initiate flows and movement, others don't; some are more on the receiving-end of it than others; some are effectively imprisoned by it" (1991, p. 26). Sally Jones is both in charge of mobility, and restricted through repeated imprisonment. Ana Molina moves from imprisonment to being in charge of more than her own mobility; she initiates global movement through her music. Her voice spreads and becomes famous not merely in Lisbon, but the entire world, and when Sally Jones is imprisoned at the maharaja's palace, it is Ana's music- - her voice-that eventually leads to Sally's liberation.

In this perspective, the maharaja is the most interesting character. $\mathrm{He}$ is the most complex person in the novel from both a cultural and literary perspective. Indian princes played a complex role in the power dynamics of colonial India; they held relatively autonomous power over their territories, and their cooperation with the British is considered a vital factor in the success of British imperialism. In India's Princely States, historians Ernst and Pati (2007) suggest that the British granted Indian princes a measure of governmental power to prevent a "striving toward independence", and so "encouraged Indian rulers to conceive of themselves, against the odds of their actual political impotence, as potent heads of independent states". Thus, as a cultural figure, the maharaja in The Murderer's Ape is ambivalent: ruler and subject at the same time. As a fictional character, 
he is the most dynamic person in the novel. In her analysis of Sally Jones, Posti (2017) stresses that Wegelius intentionally activates stereotypes in order to undermine them. This becomes very clear in the depiction of the maharaja. Indian rulers are often reductively described as cruel despots or British puppets (cf. Ernst and Pati, 2007, p. 2), and initially, Wegelius presents the maharaja in a wholly negative way. He is obscenely rich and treats his fellow humans as objects to be used as he likes-from the women he imports to populate his zenana to the ministers whose fate he decides based on their ability to play chess. His evil inclinations and his relative power over the British are shown when the greedy businessman Mr. Thursgood-who gives Sally Jones to him in hopes of gaining permission to search for diamonds in the maharaja's territory-is humiliated and sent away after losing to the gorilla in a game of chess. The narrator comments that there is "something cruel about the smile that played on his full sensual lips" (Wegelius, 2014/2017, p. 302), and even the maharaja's mother calls him a "tyrant", describing him as "a stupid bully and an incurable sensualist. Just like his father and his father's father" (2014/2017, p. 328). The references to cruelty and sensuality evoke Western stereotypes of the Oriental, as analyzed by Said in both Orientalism (1978) and Culture \& Imperialism (1993). In the latter, Said remarks sarcastically: "Statements like "The Hindu is inherently untruthful and lacks moral courage' were expression of wisdom" (Said, 1993, p. 193). Furthermore, the maharaja acts irrationally and impulsively and prefers to spend his time pursuing pleasure rather than governing his princedom and helping his starving subjects. He only listens to his ministers on Mondays, and he does so while sitting on a throne that is a toilet in disguise, allowing him to relieve himself after the weekend's heavy drinking and eating. The hyperbolic depiction of the maharaja and the grotesque description of his toilet throne all serve to paint him in a negative and stereotypical light. However, during the course of the narrative, the maharaja gets more complex and eventually becomes Sally Jones' friend. His development as a character is closely linked to his geographic mobility.

While the maharaja is in control of his territory and the people living on his land, his own geography is remarkably limited. The two maps of the maharajaone map visualizes his movements, while the other shows his connections to the world by cultural and commercial exchange-show his lack of mobility but also global connection (Fig. 6).

The maps expose a discrepancy between the maharaja's physical mobility and his actual involvement with the world. Although he owns means of transport: several Rolls Royces, a private train station, a luxurious boat and-eventually-a plane, he never moves beyond the borders of India. His restricted mobility symbolizes his limited power in British India; he is, as Massey might put it, imprisoned by imperialism. On the other hand, he initiates global movement. As the second map shows, the maharaja is globally connected: he learned chess from a German master, plays British cricket, and buys pearls from Bahrain, chocolate from Belgium and champagne from France. He is obsessed with music and gossip from Europe and America, and his wives come from Los Angeles, Milano and Paris, among other places. The maharaja, like all of India, is what Bhabha (2004) calls a cultural hybrid. 

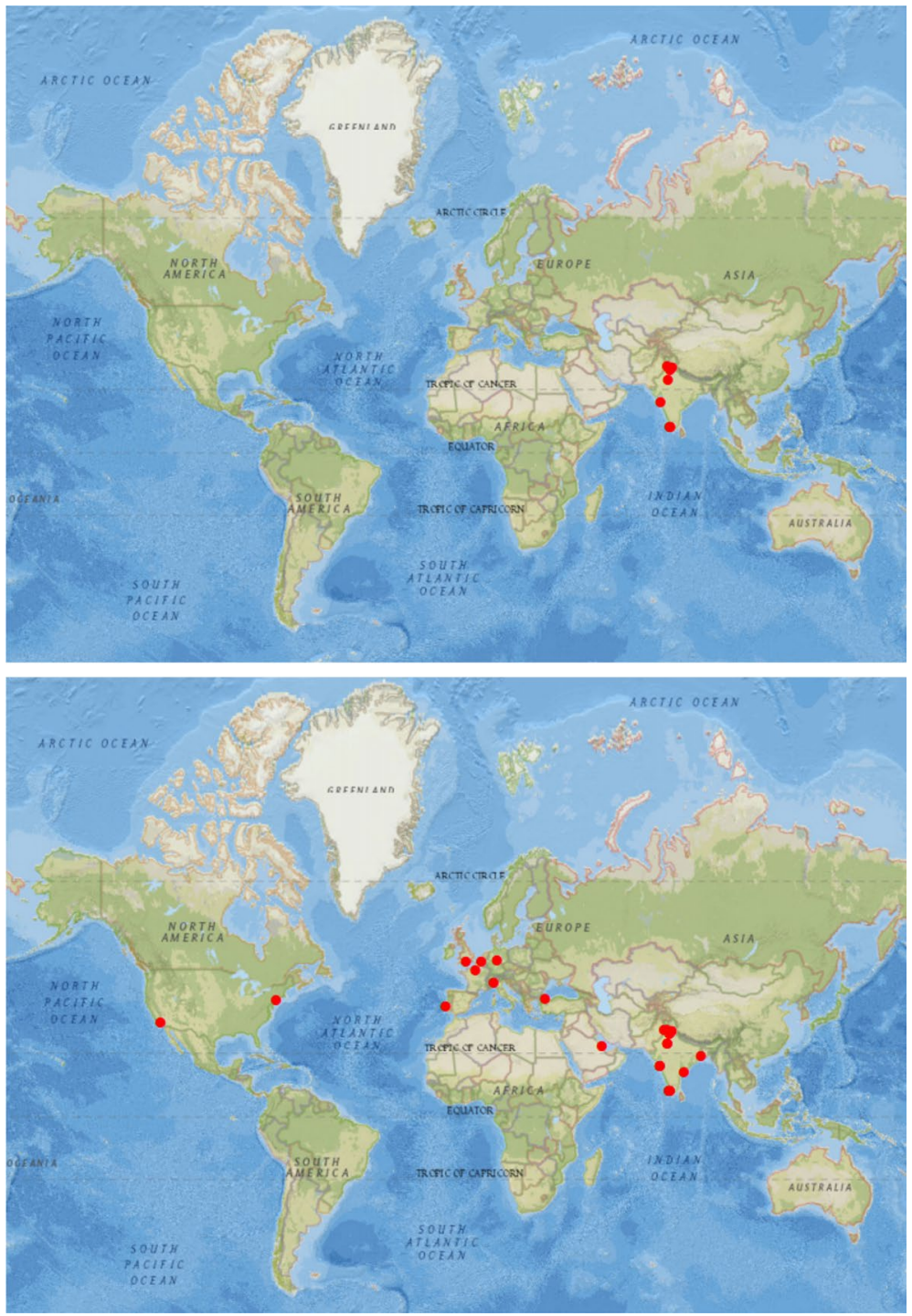

Fig. 6 The maharaja's maps

His lack of mobility is also symbolic of the maharaja's character: he lacks perspective, and thus neglects the needs of the people he rules over. When he acquires a plane and begins to fly over his princedom with Sally Jones as a navigator, he gains new perspectives and learns to see the people around him as human beings. Initially, the plane is just one of his hobbies, serving his pleasure alone:

Our flights crisscrossed the whole of Bhapur, and we were often away from early morning to late evening. Very soon all the maharaja's subjects had 
seen his plane more than once. If we landed in a field or meadow to eat lunch we would quickly be surrounded by a small crowd. The maharaja usually behaved as though they didn't exist. Dirty children, thin women and men bowed and worn by toil seemed to affect him badly. Deep down I believe he was rather afraid of them. (Wegelius, 2014/2017, p. 351)

On these early trips, the maharaja gains an overview of his territory as abstract space, and regards the people who live there-his subjects-as objects that he does not wish to come near, and that he may even fear. In Lefebvrian terms, he conceives space. However, after an emergency landing in a small village near the border to Patiala, that space gains meaning, and he perceives space as well. The land becomes more than owned property for him; it becomes lived practice. Unable to continue the trip, he and Sally Jones are forced to spend time in the village, where the villagers provide them with food, shelter and help with the repairs. The maharaja is disgusted by the food and refuses to eat; when he returns to the palace, however, he orders his ministers to dig a well and build houses: "'You do understand what I mean, don't you?' The maharaja snapped angrily. 'The next time I have to make an emergency landing in that village I want it to be a bit more comfortable"' (Wegelius, $2014 / 2017$, p. 352). Although his alleged reason is egocentric, his double motive is clear. Through his interaction with the villagers, the maharaja begins to see his subjects as fellow human beings, and his land as a place where people live their daily life, nourished by the soil they inhabit.

\section{Constructing the Utopia of Free Globalism: Closing Remarks}

Travel lies at the heart of the novel. Sally Jones is in transit in Lisbon, she travels to India, and she explores parts of India with the maharaja. As argued, Wegelius establishes two rival senses of space. In her reading of The Legend of Sally Jones, Posti (2017, p. 195) asserts that Wegelius rewrites the colonially influenced adventure genre by evoking and undermining it at the same time. My geographic analysis in this article confirms and expands this assertion. In Wegelius' novel, travel is not connected with conquest; it is instead a source of knowledge linked to the humanistic ideal of Bildung. ${ }^{3}$ The Murderer's Ape de-emphasizes the idea of nations and national territory as well as cultural boundaries. In her study on settlement narratives in children's fiction, Bradford (2007) finds that place is infused with cultural specificities and liminal places where culture is negotiated. In The Murderer's Ape, however, space and place are political, but rarely culture-specific; we have the naming of places, fado singing and Signor Fidardo's Italian temper, but culture is never depicted as a boundary. Neither is language; the novel's characters always understand each other perfectly - a more fantastic element than even the gorilla narrator.

The catalyst of the novel's intercultural communication is the narrator herself. In their reading of the novel, Palo and Manderstedt (2019, p. 129) stress the subversive

3 This is the main argument Anne Berit Lyngstad and I make in a forthcoming article. 
power inherent in Sally Jones' intersectionality: “In Wegelius's fictional society, what would have been inappropriate for human beings emerges as a cross-border that creates opportunities beyond gender" - and let me add, beyond culture and nationality, as well. Through Sally's eyes, the reader sees the colonial world from the viewpoint of someone who is neither colonizer nor colonized and has no interest in conquest, borders or territory. Both the non-colonial rewriting of the adventure genre and the construction of a utopia in which globalism is freedom are also reflected in the undermining of the home-away-home structure (cf. Lyngstad and Samoilow, 2022, forthcoming). Early on, the narrator establishes herself as homeless in the sense of not having an origin: "Most of my kind live in Africa, in the thick jungle along the banks of the Congo River, and that's probably where I originally came from. I don't know how I ended up among people, and I probably never shall know" (Wegelius, 2014/2017, p. 3). She may have been born somewhere along the Congo, but that is not where she belongs, and she is not at home among her kind. She is not African, as Posti (2017, p. 191) suggests; she transcends any cultural origin. Sally Jones is anchored not by heritage or nationality, but by her friendships with people from around the world: the Finnish captain Koskela, the Portuguese fado singer Ana Molina and her Italian neighbour Signor Fidardo, the English shipper Anderson on the Song of Limmerick, and the Indian maharaja. In The Murderer's Ape, home is not a static safe haven, but where you connect with others-and that is where you belong. Lisbon, the topographical point of departure and return, is merely a stop along the way. According to Nodleman (2008, p. 61), home and away is a pattern that "works to attach opposing values"-but in Wegelius' novel, the binary opposition between home and away is dissolved. Here, home is not a place; home is where friends are, and is so everywhere and nowhere.

Wegelius creates two rival spaces in the novel: a colonial, repressive space and a free, global space without borders that allows living beings and cultural goods and ideas to move and connect freely. Geographic analysis reveals the novel's transcension and undermining of borders and its utopian dream of real globalism based on humanist principles. This article has concentrated solely on the novel The Murderer's ape. Further explorations should be made into the novel's prequal The Legend of Sally Jones and it's sequal The False Rose (2021).

Funding Open access funding provided by NTNU Norwegian University of Science and Technology (incl St. Olavs Hospital - Trondheim University Hospital). NTNU.

Data Availability Data transparency.

Code Availability Software application or custom code.

\section{Declarations}

Conflict of interest The authors declared that they have no conflict of interest.

Consent to Publication The author has permitted the use of illustrations. 
Open Access This article is licensed under a Creative Commons Attribution 4.0 International License, which permits use, sharing, adaptation, distribution and reproduction in any medium or format, as long as you give appropriate credit to the original author(s) and the source, provide a link to the Creative Commons licence, and indicate if changes were made. The images or other third party material in this article are included in the article's Creative Commons licence, unless indicated otherwise in a credit line to the material. If material is not included in the article's Creative Commons licence and your intended use is not permitted by statutory regulation or exceeds the permitted use, you will need to obtain permission directly from the copyright holder. To view a copy of this licence, visit http://creativecommons.org/licen ses/by/4.0/.

\section{References}

Anderson, Benedict. (2014). Imagined Communities. Reflections on the Origin and Spread of Nationalism. London: Verso.

Bhabha, Homi K. (2004). The Location of Culture. Routledge.

Bradford, Clare. (2007). Unsettling Narratives. Postcolonial Readings of Children's Literature. Waterloo: Wilfrid Laurier University Press.

Bushell, Sally. (2015). Mapping Victorian Adventure Fiction: Silences, Doublings, and the Ur-map in Treasure Island and King Solomon's Mines. Victorian Studies, 57(4), 611-637.

Ernst, Waltraud, and Pati, Biswamoy (Eds.). (2007). India's Princely States. People, Princes and Colonialism. London: Routledge.

Goga, Nina. (2015). Kart i barnelitteraturen. Kristiansand: Portal.

Harley, John Brian. (2002/1989). Deconstructing the Map. In J. B. Harley and Paul Laxton (Eds.), The New Nature of Maps. Essays in the History of Cartography (pp. 149-168). Baltimore: John Hopkins University Press.

Hegglund, Jon. (2012). World Views. Oxford: Oxford University Press.

Hunt, Peter. (2015). Unstable Metaphors: Symbolic Spaces and Specific Places. In Maria Sachiko Cecire, Hanna Field, Kavita Mudan Finn and Malini Roy (Eds.), Place and Space in Children's Literature 1789 to the Present (pp. 23-37). Surrey: Ashgate.

Johnsrud, Birgitte. (2020). Møte med sted i en fiktiv og en virkelig verden. Mördarens apa og bruk av digitale verktøy. In Åse Høyvoll Kallestad and Marianne Røskeland (Eds.), Sans for danning. Estetisk vending i litteraturdidaktikken (pp. 165-176). Oslo: Universitetsforlaget.

Lefebvre, Henry. (1991). The Production of Space. Oxford: Blackwell.

Lyngstad, Anne Berit, and Samoilow, Tatjana Kielland. (2022, forthcoming). Det kosmopolitiske mulighetsrommet i Jakob Wegelius' Mördarens apa (2014). In Agora. Journal for metafysisk spekulasjon. No. 2-3.

Merrifield, Andrew (1993). Place and Space: a Lefebvrian Reconciliation. Transactions of the Institute of British Geographers, 18(4), 516-531.

Massey, Doreen. (1991). A Global Sense of Place. Marxism Today, June, 24-29. Accessed April 18, 2021 from http://banmarchive.org.uk/collections/mt/pdf/91_06_24.pdf

Moretti, Franco. (1998). Atlas of the European Novel. 1800-1900. London: Verso.

Nodleman, Perry. (2008). The Hidden Adult. Defining Children's Literature. Baltimore: John Hopkins University Press.

Page, Melvin Eugene, and Sonnenburg, Penny M. (2003). Colonialism. A Social, Cultural, and Political Encyclopedia (Vol. 1). Santa Barbara: ABC Clio.

Palo, Annbritt, and Manderstedt, Lena. (2018). Bildens status i läsarkommentarer på nätet. Narrativ interaktion i Jakob Wegelius Legenden om Sally Jones och Mördarens apa. Barnboken, 41. Accessed April 18, 2021 from https://doi.org/10.14811/clr.v41i0.336.

Palo, Annbritt, and Manderstedt, Lena. (2019). Beyond Characters and the Reader? Digital Discussions on Intersectionality in The Murderer's Ape. Children's Literature in Education, 50(1). Accessed April 18, 2021 from https://doi.org/10.1007/s10583-017-9338-2.

Pavlik, Anthony, and Bird, Hazel Sheeky. (2017). Introduction: Maps and Mapping in Children's and Young Adult Literature. Children's Literature in Education, 48, 1-5. Accessed April 18, 2021, from https://doi.org/10.1007/s10583-016-9303-5 
Piatti, Barbara, Bär, Hans Rudolf, Reuschel, Anne-Kathrin., Hurni, Lorenz, and Cartwright, William (2009). Mapping Literature. Toward a Geography of Fiction. In William Cartwright, Georg Gartner and Antje Lehn (Eds.), Cartography and Art, (pp. 179-194). Berlin: Springer.

Posti, Piia. (2017). Resor, äventyr och den andre: Exotism och det främmande i samtida svensk barnlitteratur. In Maria Andersson and Elina Druker (Eds.), Mångkulturell barn- och ungdomslitteratur: Analyser (pp. 181-197). Lund: Studentlitteratur.

Robinson, Will. (2014). Orientalism and Abstraction in Eurogames. Analog Game Studies, 8(1). Accessed April 18, 2021 at: https://analoggamestudies.org/2014/12/orientalism-and-abstraction-ineurogames/

Said, Edward. (1993). Culture and Imperialism. London: Vintage.

Said, Edward. (1978). Orientalism. London: Penguin Books.

Sundmark, Björn. (2019). Maps in Children's Books: From Playworld and Childhood Geography to Comic Fantasy and Picturebook Art. Filoteknos, 9, 123-137. Accessed April 18, 2021, from https:// doi.org/10.23817/filotek.9-9.

Thacker, Andrew. (2017). Critical Literary Geography. In Robert T. Tally Jr. (Ed.), The Routledge Handbook of Literature and Space (pp. 28-38). London: Routledge.

Wegelius, Jakob. (2008a). The Legend of Sally Jones. Peter Graves. London: Puskin Press.

Wegelius, Jakob. (2008b). Legenden om Sally Jones. Stockholm: Bonnier Carlson.

Wegelius, Jakob. (2014). Mördaren's apa. Stockholm: Bonnier Carlson.

Wegelius, Jakob. (2017). The Murderer's Ape. Trans. Peter Graves. London: Pushkin Press.

Wegelius, Jakob. (2020). Den falska rosen. Stockholm: Bonnier Carlson.

Wegelius, Jakob. (2021). The False Rose. Trans. Peter Graves. London: Pushkin Press.

Publisher's Note Springer Nature remains neutral with regard to jurisdictional claims in published maps and institutional affiliations. 